INTERNATIONAL JOURNAL OF RESEARCHES IN BIOSCIENCES, AGRICULTURE \& TECHNOLOGY (C) VISHWASHANTI MULTIPURPOSE SOCIETY (Global Peace Multipurpose Society) R. No. MH-659/13(N)

www.vmsindia.org

\title{
HISTOARCHITECTURAL STUDIES ON THE ADRENAL GLAND OF MALE BAT, HIPPOSIDEROS LANKADIVA
}

\author{
Amir A. Dhamani \\ Gramgeeta College Chimur, Chandrapur (M.S) India \\ Email:dhamaniamir@gmail.com
}

\begin{abstract}
The present study shows the cyclical alternation in the activity of adrenal gland of the bat Hipposiderous lankadiva during sexually quiescence and sexually active period of the reproductive cycle. The adrenal gland is made up of steroidogenic and chromaffin cells. The gland during sexually quiescence period is much smaller than that of sexually active period. The cortex is completely encircles the medulla in Hipposideros lankadiva. The medulla in this species consists of epitheloid cells arranged in smaller groups surrounded by blood capillaries. The Zona glomerulosa consist of numerous bulbous structures which appear as acinus like group of cells. The Zona fasciculata is seen in the form of straight column; one or two cells thick arranged radially that run toward the center of the gland. These cords consist of large polyhedral vacuolated cells. The Zona reticularis has the cells disposed in the form of anastomosing cords and vary in shape and size. The cells are hypertrophied. Cytoplasm is eosinophilic with darkly stained nucleus and more vacuolated. Medulla is entirely surrounded by cortical zone it consist of groups of chromatin cells separated by blood capillaries.
\end{abstract}

Keywords:- Hipposideros lankadiva ,Zona fasciculate, Anastomosing

\section{Introduction:}

A primary function of the adrenal gland is to protect the organism against acute and chronic stress. In acute stress, catecholeamines of the medulla mobilize glucose and fatty acids for energy and prepare the heart, lungs and muscles for action. Glucocorticoids protect against over reactions of the body's responses to stress and, in the more chronic stress of food and fluid deprivation, stimulate gluconeogenesis to maintain the supply of glucose. Stress as well as hyper- and hypofunction of the adrenal gland is known to suppress reproduction in mammals. [9].

This species do not have wide distribution as the colonies are very rare and far from each other. Mammalian adrenal is unique among the vertebrate where the steroidogenesis and chromaffin cells are separated as cortex and medulla respectively. The light microscopic observations of adrenal gland are known in few species of bats viz., Eptrsicus fuscus and Anatrozous pallidus Anatrozous pallidus [3] Megaderma lyra lyra [1] Miniopterus schreibersii[8] Rousettus leschenauti and Pteropus gigantius [10] Cynopterus sphinx and Taphozous longimanus[4] Taphozous melanopogon [5] Taphozous kachhensis[2].
The study of weight, size and shape of right and left adrenal gland in pregnant and nonpregnant bat show the significant difference in Taphozous melanopogon [5]. The objective of present study is to analyse the histoarchitectural changes in the adrenal gland of the female bat Hipposiderous lankadiva during sexually quiescence and sexually active period.

\section{Material and methods:}

The specimens of Hipposideros lankadiva were collected from Chandrapur and Ballarshah (Longitude79, 21 East and Latitude 19,55 North) and (Longitude79, 23 East and Latitude 19,55 North) about 130 $\mathrm{km}$ Bramhapuri. Many collections were made during the breeding season so as to coincide with the time of reproductive cycle. During the day time, their roosting places were visited and sometime during night and the specimens were netted at random with the help of a butterfly net. After collection they were sexed and only the males were brought to the laboratory. Weight was recorded with sensitive spring balance before they were sacrificed. For histological observations the tissue were dissected out and fixed in alcoholic Bouin's fluid. After fixation for $24 \mathrm{hr}$ tissue were washed with $70 \%$ ethanol. For histological observation, 
the tissues were later dehydrated in various grades of alcohol, cleared in xylol, and embedded in paraffin wax. The tissues were cut at 5 to $6 \mu$ with the help of Leica 2417 microtome the sections were stained with haematoxylin and eosin for routine histological examination.

\section{Observations:}

The adrenal gland of Hipposideros lankadiva are situated retroperitionally abutting against the ipsilateral kidneys to which it is firmly attached by the renal fascia. The adrenal gland can be distinguished as an outer cortex and inner medulla, even though a distinct circum medullary connective tissue capsule separating the two regions is missing. The medulla is relatively extensive in this species of bat. The cortex completely encircles the medulla in Hipposideros lankadiva. Measurement of the weight of adrenal gland during the reproductive cycle is represented in the Table: 1

Table-1. Weight of the adrenal gland during different phases of the reproductive cycle.

\begin{tabular}{|l|c|r|r|r|r|r|r|r|r|}
\hline $\begin{array}{l}\text { Month of } \\
\text { collection }\end{array}$ & $\begin{array}{c}\text { Reproductive } \\
\text { phases }\end{array}$ & \multicolumn{3}{|c|}{$\begin{array}{c}\text { weight of the right } \\
\text { adrenal gland }\end{array}$} & \multicolumn{2}{c|}{$\begin{array}{c}\text { Avg. } \\
\text { weight }\end{array}$} & \multicolumn{2}{c|}{$\begin{array}{c}\text { weight of the left } \\
\text { adrenal gland }\end{array}$} & $\begin{array}{c}\text { Avg. } \\
\text { weight }\end{array}$ \\
\hline February & Inactive & 1.67 & 1.68 & 1.66 & 1.67 & 1.72 & 1.74 & 1.7 & 1.72 \\
\hline June & Pre-breeding & 2.37 & 2.35 & 2.39 & 2.37 & 2.65 & 2.69 & 2.67 & 2.67 \\
\hline August & Active breeding & 2.68 & 2.66 & 2.67 & 2.67 & 2.91 & 2.93 & 2.92 & 2.92 \\
\hline November & Post- breeding & 3.17 & 3.19 & 3.15 & 3.17 & 3.5 & 3.52 & 3.54 & 3.52 \\
\hline
\end{tabular}

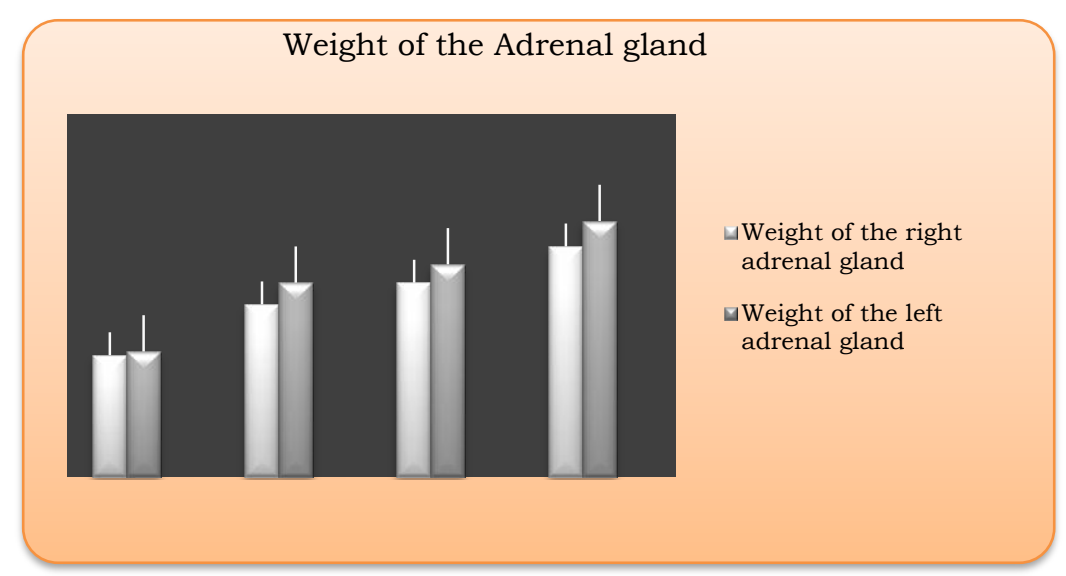

Histogram 1- Weight of the adrenal gland during different phases of the reproductive cycle. 
Bat collected during the month of February are sexually inactive and the weight of the right adrenal gland is $1.67 \mathrm{mgs}$ and that of left is 1.72 mgs. The weight of the gland increases in the month of June during pre breeding i.e $2.37 \mathrm{mgs}$ for right and $2.67 \mathrm{mgs}$ for the left adrenal gland.

The weight of the adrenal gland shows significant increases during the active breeding phases as compared to inactive phases of the reproductive cycle i.e 2.67 mgs for right and $2.92 \mathrm{mgs}$ for the left adrenal gland. While during post breeding period a slight decline in the weight of the adrenal gland as compared to pre -breeding months.

Light microscopic studies of the Adrenal glands:

Adrenal gland during the sexually quiescence period:

Adrenal gland of Hipposideros lankadiva is round to oval in shape and encloses in a connective capsule made up of spindle fibrous cells. Thin strand of connective tissue or trabeculae extend from capsule between the columns of cells in the cortex. Beneath the capsule, glands have two distinct zonations the cortex and medulla. On the basis of the observations on histology of the steroidogenic cells, cortex is further divided in to three zones namely zona glomerulosa, zona fasciculata and zona reticularies.

\section{Zona glomerulosa}

This is the smallest cortical zone of adrenal measuring upto $72 \mu$ during the sexually quiescence period. This zone consists of polyhedral cells that are compactly arranged and appear acinus like group of $4-6$ cells. These cells have darkly stained nucleus. Chromatin clumps are observed at the periphery of the nuclear membrane. Cytoplasm is eosinophilic and granular. Vacuoles are observed in the cytoplasm of some cells. (Fig. 1).

\section{Zona fasciculata}

This is the widest cortical zone observed in the adrenal cortex measuring $132 \mu$ during sexually quiescence period. Zona fasciculata consist of large polyhedral or cuboidal cells arranged in straight cords. Cytoplasm is eosinophilic and vacuolated, spongy due to the presence of lipid droplets. Nucleus is darkly stained and vesicular. Zona fasciculata merges with Zona glomerulosa above and Zona reticularis below. The cords are separated from each other by connective tissue and blood capillaries (Fig 2).

\section{Zona reticularis}

This zone is present just below the Zona fasciculata and measure about $98 \mu$ in diameter during sexually quiescence period. The cells of Zona reticularis are in the form anatomizing cords and having varying degree of shape and size. Each cell has eosinophilic cytoplasm with vesicular nucleus. Dense chromatin material observed near the periphery of the nucleus. Very few lipid vacuoles observed in the cell cytoplasm. Blood spaces are observed in the network of cell cords (Fig. 3).

\section{Medulla}

Medulla is clearly demarcated from the cortex in Hipposiderous lankadiva. It measure about $270 \mu$ in diameter during the sexually quiescence period. Medulla consist of cells arranged in irregular strands or short cords surrounded by blood capillaries. Cells contain darkly stained vesicular nucleus. Cytoplasm of cell is basophilic and granular. Chromatin clump are observed toward the periphery of the nucleus. (Fig. 4).

\section{Adrenal gland during the sexually active period:}

Bat collected in the month of August are active males showing vigorous

spermatogenesis in their testis. Adrenal gland collected in the month of August shows distinct medullary and cortical zones, measuring $360 \mu$ and $380 \mu$.

\section{Zona glomerulosa}

Zona glomerulosa is the smallest zone and measure about $102 \mu$ in diameter. Cell of glomerulosa are elongated with darkly stained nuclei. Cytoplasm is eosinophilic and Vacuolations are observed in cytoplasm which are more as compared to Zona glomerulosa during sexually inactive period. (Fig 5).

\section{Zona fasciculata}

This is the largest zone of the cortex and measure about $148 \mu$ in diameter. This Zone occupies greater area as compared to the sexually inactive phase. The cells are hypertrophied and nucleus is vesicular, 
round and darkly stained. The cytoplasm is eosinophilic and more vacuolated. (Fig 6)

\section{Zona reticularis}

Zona fasciculata merge with Zona reticularis without any clear demarcation. Zona reticularis is increase in size and measures $105 \mu$ in diameter. The cells are hypertrophied. Cytoplasm is eosinophilic with darkly stained nuclei and more vacuolated. One or two nucleoli are observed in the nucleoplasm and few chromatin clump are also seen in nucleus. Blood capillaries are also reduced in this zone (Fig.7).

\section{Medulla}

Medulla is more developed during sexually active period and measure about $580 \mu$ in diameter. Hypertrophied medullary cells are arranged in the acini encircling the blood spaces. Cell cytoplasm is lightly stained and granular with vacuolation. Blood supply is also increased and blood vessels are observed encircling the cells. Two types of cells are not identified in the adrenal gland of sexually active bat because of fixative and regular staining technique are not sufficient for this purpose (Fig. 8).

\section{Discussion}

In Hipposideros lankadiva, the size and weight of left adrenal gland is always higher than the right adrenal gland during different phases of the reproductive cycle. Similar observations are reported in $T$. melanopogon [5]. The weight of the adrenal gland is maximum during active breeding period. It decreases during inactive period. The cortex and medulla of adrenal gland of bat, Hipposideros lankadiva are clearly marked. Similar observations were made in the bat, M. lyra lyra [11], Taphozous kachhensis [2] R. leschenaulti [10], Taphozous longimanus [7].

The adrenal gland in this species of female bat is oval to oblong in shape and is enclosed in the connective tissue capsule. Beneath the capsule lies a small cortical zone, the Zona glomerulosa. It consists of numerous acinus like group of cells. Similar structure is also reported in the Zona glomerulosa of Taphozous longimanus [4]. However, the cells are arranged in columns in $R$. leschenaulti [10]. The glomerulosa merges with the Zona fasciculata. The Zona fasciculata occurs in the form of irregular short cords; one or two cells thick arranged radially and merge with each other. These cords consist of large polyhedral vacuolated cells. Similar pattern of arrangement in Zona fasciculata is observed in Rousettus leschenaulti [10]. These cords are made up of two cells thick polyhedral cells in $P$. giganteus [10]. Megaderma lyra lyra [11]. The Zona reticularis is in the form of anatomizing cords of cells, which merge with zona fasciculata above and below medulla. However, Zona reticularis is absent in T. longimanus [6]. The medulla of Hipposiderous lankadiva is well developed. Cells are arranged in irregular strands or short cords surrounded by blood capillaries. Similar structure of medulla is reported in $T$. longimanus [6]. In $R$. leschenaulti and $P$. giganteus [10], have reported the presence of two types of medullary cells on the basis of staining with basic dyes.

There is no comparative baseline information available regarding the function of adrenal gland during the sexually inactive and sexually active state of male bat. However information available regarding seasonal changes in adrenal gland of female bat [5].

Zona glomerulosa is the smallest zone. Cell of glomerulosa are elongated with darkly stained nuclei. Cytoplasm is eosinophilic and Vacuolations are observed in cytoplasm which are more as compared to Zona glomerulosa during sexually inactive period.

Zona glomerulosa in the cortex occupies greater area as compared to the sexually inactive phase. The cells are hypertrophied and nucleus is vesicular, round and darkly stained. The cytoplasm is eosinophilic and more vacuolated. Zona fasciculata merge with Zona reticularis without any clear demarcation. Zona reticularis is increase in size. The cells are hypertrophied. Cytoplasm is eosinophilic with darkly stained nuclei and more vacuolated. One or two nucleoli are observed in the nucleoplasm and few chromatin clumps are also seen in nucleus. Blood capillaries are also reduced in this zone. Medulla is more developed during sexually active period. Hypertrophied medullary cells are arranged in the acini 
encircling the blood spaces. Cell cytoplasm is lightly stained and granular with vacuolation. Blood supply is also increased and blood vessels are observed encircling the cells.

The present observations are in conformity with observation reported on adrenal gland of Megaderma lyra lyra [11] and Taphozous kachhensis [2].

\section{References:}

\section{Bhima Rao, B.S. andDevaraj Sarkar (}

1975), H.B.: Cur. Sci., 44:87-94.

Chavhan, P.R., Dhamani, A.A (2011). Histological changes in the ovary of the bat Taphozous kachhensis (Dobson) during various phases of reproductive cycle. Applied biological research, vol 13, 2: 85-88.

Gorbman, A. and Bern, H.A. (1962). A text book of comparative endocrinology. John Wiley and Sons, Inc., New York

Karim K.B.,Gopalkrishna A \& Godhoke,H. (1979). Adrenal gland in two Indian bats. Curr.Sci.48: 607

Lowry, M.L. and Lall, S.B (1987). Evidence for the involvement of the adrenal gland in the gestation junction of Taphozous melanopogon (Chiroptera) displaying absolute dextral dominance of genital tract. European Bat Research, Charles Uni. Press, Praha. 161-169
Nerkar, A.A. (2007). Electron microscopic studies on the endocrine gland and reproductive organs of Emballonurid female bat Taphozous longimanus (Hardwicke) during reproductive cycle. Ph.D. Thesis submitted to Rashtra sant tukdoji maharaj .Nagpur University. Nagpur.

Nerkar, A.A. (2009). Histoarchitectural alterations in the adrenal gland of the female Emballonurid bat, Taphozous longimanus (Hardwicke) during the reproductive cycle. J. Cell Tissue Res. Vol. 9(3): 2005-2011

Planel, H., Guilhem, A. and Soleilhavoup, J.-P. (1961). Le cycle annual du cortex surrenal d'un semi-hiberant: Miniopterus schreibersii. Comptes Rendus de l'Association des Anatomistes 47,620-633.

Rivier, C., Rivier, J. and Vale,W. (1986). Stress-induced inhibition of reproductive functions: Role of endogenous corticotropinreleasing factor. Science 232, 607-609.

Sapkal, V.M., (1978). The adrenal gland of two fruit bat. Curr. Sci., 47: 140-142.

Sonwane, D.P. (2010). Endocrine Regulation of Reproduction in the Indian Female Vampire Bat Megaderma lyra lyra (Geoffroy). Ph.D. thesis submitted to Rashtra sant Tukdoji Maharaj, Nagpur University, Nagpur, Maharashtra, India.

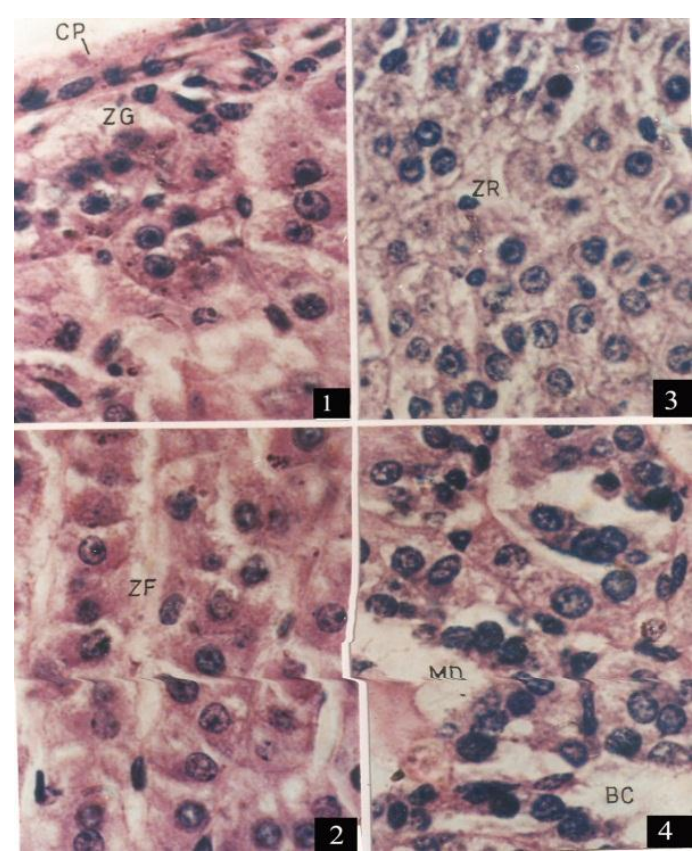

Plate 1. Fig. 1 Transverse section of adrenal gland of sexually inactive male bat. Note the presence of outer capsule (CP) followed by small acini like group of cell of Zona glomerulosa (ZG). Fig. 2 Section of adrenal gland of sexually inactive male bat showing cell cords of Zona fasciculata $(Z F)$. Fig. 3 Section of adrenal gland of sexually inactive male bat showing cell of 
Zona reticularis (ZR). Fig. 4 Section of adrenal gland of sexually inactive male bat showing inner medullary zone (MD) surrounded by blood capillaries (BC).

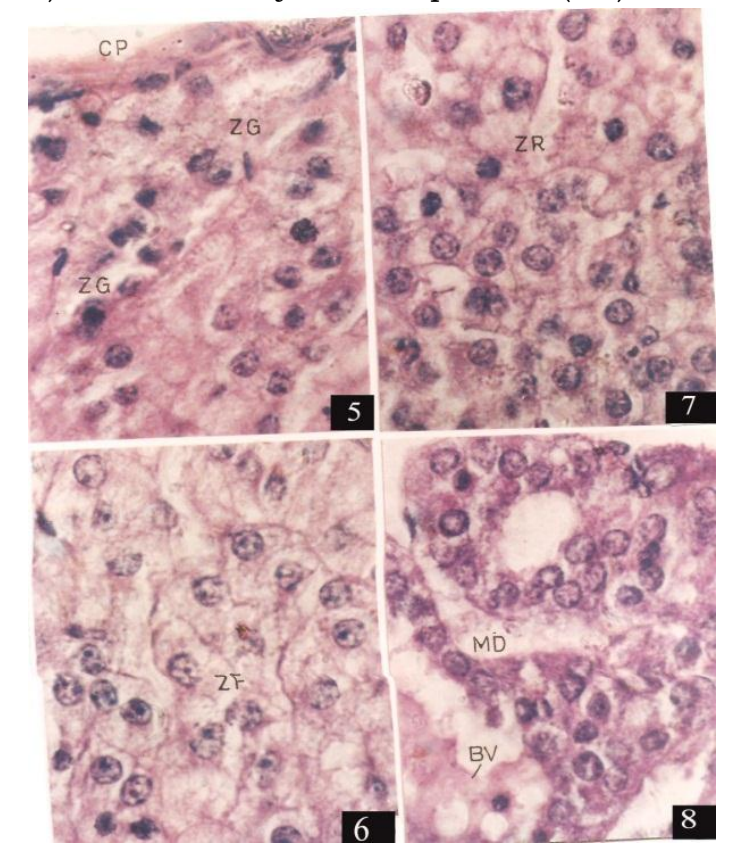

Plate 2. Fig. 5 Transverse section of adrenal gland of sexually active male bat. Note the presence of outer capsule (CP) followed by small acini like group of hypertrophied cell of Zona glomerulosa $(Z G)$. Fig. 6 Section of adrenal gland of sexually active male bat showing hypertrophied cell cords of Zona fasciculata $(Z F)$. Note the vacuolation in the cells of Zona fasciculata. Fig. 7 Section of adrenal gland of sexually active male bat showing cell of Zona reticularis (ZR). Fig. 8 Section of adrenal gland of sexually active male bat showing enlarged medullary zone (MD) surrounded by blood capillaries (BC). 